\title{
18
}

\section{Lessons and legacies of the use of force}

\author{
Peter Leahy
}

The lessons and legacies from Australia's wars in Afghanistan and Iraq neither start in 2001 nor finish in 2014.

The Australian Defence Force and the Australian Army were not ready for the war in Afghanistan, and consequently there were severe limitations on what could be done in both deployments. The ADF arrived at this situation because of decades of errant strategic guidance and an underinvestment in defence capabilities, especially the Australian Army, in the last quarter of the 20th century.

Today, there are still lessons to be learned and legacies to be realised as Australia remains engaged in both Afghanistan and Iraq. These current lessons and legacies will continue to shape the ADF of the future, but only if there is the wit and wisdom to recognise them and do something about them.

\section{Aim}

The aim of this chapter is to highlight the major lessons and legacies for the Australian Army from the deployment to the Middle East from 2001 to 2014. The chapter will propose nine lessons at the strategic and operational levels and three legacies, which have yet to be fully realised. 
Apart from acknowledging significant improvements in equipment, collective training, combined arms cooperation and the development of defensive measures against improvised explosive devices (IEDs) at the tactical level, these lessons will not be covered in any detail. Overall, care must be exercised in making tactical judgements because, as many have said, it is a poor practice to benchmark your tactical prowess against adversaries such as the Iraqi Army in 2003, and the Taliban throughout the duration of the fight in Afghanistan. In summary, the lessons and legacies to be covered are highlighted here. The nine lessons are:

- Be ready for the most likely conflict.

- Have a strategy.

- You can't go to war quickly without introducing risk.

- You can't make a flexible and versatile force out of nothing.

- Equipping the force is difficult, expensive and time consuming.

- Doctrine is important.

- When designing the force, a clear mission is essential.

- 'Whole of government' should mean whole of government.

- A combined arms approach is essential.

The three legacies are as follows:

1. any decision to go to war should be subject to parliamentary debate and vote

2. the alliance with the United States is important but it is not the only reason to go to war

3. a new community-based approach to caring for our wounded is emerging.

\section{Lessons from the British and US experience}

Several official and unofficial publications have highlighted various lessons from the perspective of the United Kingdom and the United States. 
In the case of the United Kingdom, the principal report was the Iraq Inquiry, chaired by John Chilcot, which examined the UK's policy on Iraq from 2001 to 2009. The inquiry sought to answer two questions: whether it was right and necessary to invade Iraq in March 2003; and whether Britain could — and should — have been better prepared for what followed. ${ }^{1}$

The inquiry covered an enormous amount of material, and almost exclusively dealt with Iraq. However, the value of the inquiry report is that, like Australia, Britain was a junior partner of the US-led alliance in Iraq and has had a long-term security relationship with the United States. The British lessons are therefore useful when considering the Australian position. For those who might be wondering, a similar Australian inquiry is not necessary. It would no doubt come to very similar conclusions as those reached in Britain's Iraq Inquiry.

In a very British manner, the Iraq Inquiry concluded: 'The Iraq of 2009 certainly did not meet the UK's objectives as described in January 2003: it fell far short of strategic success.'2 Another, now obvious and striking, lesson is found in the conclusion of the inquiry: 'It is now clear that policy on Iraq was made on the basis of flawed intelligence. The flawed premises were not challenged and they should have been.'

Linking the campaigns in Iraq and Afghanistan, the inquiry observed:

From 2006, the UK military was conducting two enduring campaigns in Iraq and Afghanistan. It did not have sufficient resources to do so. Decisions on resources for Iraq were affected by the demands of the operation in Afghanistan. ${ }^{4}$

The Iraq Inquiry also determined that the United Kingdom chose to join the invasion of Iraq before the peaceful options for disarmament had been exhausted. It judged that 'military action at that time was not a last resort'. ${ }^{5}$

1 J. Chilcot, 'Statement by Sir John Chilcot', in Report of the Iraq Inquiry, 6 July 2016 [hereafter Chilcot, 'Statement'], p. 1, webarchive.nationalarchives.gov.uk/20171123123519/http://www.iraq inquiry.org.uk/media/247010/2016-09-06-sir-john-chilcots-public-statement.pdf (retrieved 3 April 2020).

2 Executive Summary, Report of the Chilcot Inquiry, 6 July 2016, p. 109, webarchive. nationalarchives. gov.uk/20171123122743/http://www.iraqinquiry.org.uk/the-report/ (retrieved 3 April 2020).

3 Chilcot, 'Statement', p. 6.

4 Ibid., p. 10.

5 Ibid., p. 1. 
In relation to the preparation for what might follow the intervention, it concluded: 'The Government's preparations failed to take account of the magnitude of the task of stabilising, administering and reconstructing Iraq, and of the responsibilities which were likely to fall to the UK. ${ }^{6}$

The Economist magazine, when reporting on the inquiry release, observed that Tony Blair was not a liar or a war criminal. However, The Economist also observed that Tony Blair was a man steered by a fatal combination of hubris, wishful thinking and moral fervour into an ultimately disastrous course of action. ${ }^{7}$

Another crucial finding from the Iraq Inquiry was: 'Above all, the lesson is that all aspects of any intervention need to be calculated, debated and challenged with the utmost rigour. ${ }^{8}$

Now let us turn to the lessons from the perspective of the United States. One provocative article by Stephen M. Walt, in Foreign Policy, provides a guide to what some have proffered as lessons learned in Iraq from a US point of view. ${ }^{9}$

The first observation from Walt is that the United States lost in Iraq. Walt then notes, in a series of statements: be careful which wars you choose; boneheaded decisions follow when there is no open debate about what to do; and the United States did not really understand Iraq and relied too much on 'ambitious exiles' for advice and intelligence. Walt also notes that the force must be prepared to adjust, that regional allies are required and that you should not assume that their interests are the same as yours. In yet another lesson, he records that 'winning a battle is easy when you have an overwhelming force and then, winning the occupation or the peace via a counter-insurgency campaign is a whole lot harder to do'.

In conclusion, Walt states, 'The real lesson of Iraq is not to do stupid things like this again. ${ }^{10}$

6 Ibid., p. 9.

7 Economist, 'Iraq's grim lessons', 6 July 2016, www.economist.com/britain/2016/07/06/iraqs-grimlessons (retrieved 3 April 2020).

8 Chilcot, 'Statement', p. 12.

9 S.M. Walt, 'Top 10 lessons of the Iraq War', Foreign Policy, 20 March 2012, foreignpolicy.com/ 2012/03/20/top-10-lessons-of-the-iraq-war-2 (retrieved 3 April 2020).

10 Ibid. 


\section{The time before 2001}

In America's First Battles, the authors review such battles as Buna and Kasserine Pass in the Second World War, Task Force Smith in Korea and the Ia Drang Valley in Vietnam and conclude that the US Army was ill-prepared for all its first battles from 1776 to 1965. A similar conclusion could be made for Australia's first battles. ${ }^{11}$

In 2001 many in the Australian Army were veterans of what General David Hurley famously called the 'Long Peace'. Over this period, roughly from the early 1970s until the late 1990s, the Australian Army largely remained at home. Apart from a small number of UN postings and a brief burst of deployments around the early 1990s with operations in Cambodia, Somalia and Rwanda, about the only thing the Army did was get smaller. ${ }^{12}$

After these uncommon deployments, a few Army thinkers began researching the most likely nature of future wars. They were influenced by such authors as Robert Kaplan in The Coming Anarchy and Paul Kennedy in The Troubled and Fractured Planet. ${ }^{13}$ These Army thinkers agreed with the judgements in successive Defence White Papers that a direct assault on the Australian continent was unlikely. In their view, the defence capabilities required were those with global reach to deal with wars among populations in distress away from Australian shores. These ideas took hold inside the Army but did not spread much further.

Instead, under the powerful 'Defence of Australia' policy, the Army was assigned the role of 'goalkeeper' against a mythical enemy. In the 'Army 21' review of the mid-1990s, the Army was given strategic guidance that its primary task was to defeat an understrength enemy raider battalion somewhere in the north of Australia. Predictably, these infamous 'thugs in thongs' never came. Strategic guidance, which favoured naval and air forces to interdict an invasion across the sea-air gap to Australia's north, was wrong. The Army languished, as a home-only force, without realistic guidance and an inadequate budget.

11 C. Heller and W. Stofft (eds), America's First Battles, 1776-1965, University of Kansas Press, Kansas, 1986.

12 From approximately 34,000 around the time of the withdrawal to around 25,000 around the time of the deployments to Afghanistan and Iraq.

13 T. Frame and A. Palazzo (eds), On Ops: Lessons and Challenges for the Australian Army Since East Timor, UNSW Press, Sydney, 2016, p. 64. 
The 1994 Defence White Paper contained an assumption that the ADF would force structure for the defence of Australia. Resourcing for expeditionary tasks was to be in the 'margins'. The margins were tightly controlled and were estimated to be around 15 per cent. This was not enough to ensure that the Army was ready for the missions and tasks that would be required within the next decade.

After the change of government in 1997, the focus on continental defence began to change subtly and strategic guidance began to shift ever so slightly to an offshore role for the Army. However, the change in guidance did not permeate adequately through to strategic guidance, resourcing and capability development to result in meaningful and timely changes to force structure and preparedness of the ADF and Army before East Timor.

East Timor was a bit of a wake-up for the ADF. I say 'bit of a wakeup' because even by October 2001, when the deployment to Afghanistan began, the lessons of East Timor had not been fully understood, interpreted and implemented. The reality of East Timor was that the ADF struggled even when faced with such a geographically close and relatively benign task. There were significant deficiencies in strategic lift, communications, logistics over the shore, joint and combined operations, equipment stocks, coalition management, force preparedness and readiness. But at least East Timor did bring about a growing realisation that the defence force that faced the last battle of the 20th century was not the defence force needed to face Australia's first battles of the 21 st century.

The reader might wonder about the relevance of this preamble, but it gets to the core issue of getting the strategy right. We in Australia have a patchy record on this account, but we are not alone. The British author and strategic thinker Basil Liddell Hart defined strategy as the calculation and coordination of ways and means to achieve ends. It is difficult to reconcile Liddell Hart's strategic equation with the situation in both Afghanistan and Iraq. Just what were the ends, and were the right ways and means applied?

Could anyone then and can anyone now answer three basic questions for both Afghanistan and Iraq: what is the shape of peace, what does victory look like, and what is the exit strategy?

The lessons of both Afghanistan and Iraq, at the strategic level, belong mostly to the United States. As Neil James from the Australia Defence Association states, Australia is a strategy taker, not a strategy maker. The United States took the policy lead in Afghanistan and Iraq at the 
beginning of both conflicts, and Australia largely acquiesced to the US strategy and narrative for both conflicts. Although Australia sought to contribute to the strategic discourse, it had limited influence. Indeed, how much impact can be expected from any individual nation in large coalitions such as those involved in Afghanistan and Iraq? The US-led anti-Islamic State or Daesh coalition has consisted of more than 50 nations - try finding consensus among that lot!

In October 2001, there was a clear objective in Afghanistan: kill al-Qaeda and their Taliban supporters in revenge for the 9/11 attacks and take away their sanctuaries and bases in Afghanistan. Vengeance might feel good, but it is not an adequate strategic objective.

In the years since al-Qaeda fled from Afghanistan across the border into Pakistan, after the battle of Tora Bora, it is difficult to identify a clear and constant strategy for Afghanistan. Instead, there has been a parade of missions and regularly changing force structures and force levels contributing little to an overarching and consistent strategy and a clear focus on an agreed and achievable end state.

As this chapter was being written, the overall situation in Afghanistan looked dire. In February 2017, in testimony to the Senate Armed Services Committee, the US commander in Afghanistan, General John Nicholson, warned that US troop levels were not adequate to prevent the Taliban from continuing to retake territory, especially in Helmand Province, the heartland of the insurgency. Senator John McCain at the same Senate hearing suggested that instead of playing 'not to lose', the United States needed a strategy to defeat the Taliban.

When it comes to Australia's lessons from the war in Iraq, the Australian defence official, Al Palazzo, has done the Australian public a service through his observations and conclusions in his report on Iraq, The Australian Army and the War in Iraq: 2002-2010. Although the report does not incorporate Cabinet and other high-level government documents, it is a good start to understanding Australia's involvement in Iraq and is an important contribution to the development of the lessons and legacies of Iraq. The journalist David Wroe, from the Sydney Morning Herald, when releasing the book, wrote:

The report concludes that Howard joined US President George W. Bush in invading Iraq solely to strengthen Australia's alliance with the US ... The result was a contribution that was of only modest military use and, in many cases, made little sense. Politically, 
delivering the right force was secondary to the vital requirement of it just being there ... yet frustrated commanders often asked what they were doing in Iraq and many took to writing their own mission statements. One commander wryly summed up his time in Iraq thus: 'We did some shit for a while and things didn't get any worse. ${ }^{14}$

There is a problem with Australia's strategic approach to Iraq. The problem relates not so much to the initial decision to depose Saddam Hussein but with what happened after he was removed. Few predicted the development of a nationwide insurgency, nor did they foresee the unleashing of local and regional sectarian forces, which have led to turmoil and instability in Iraq and many regional states. The overconfidence and ignorance of local conditions of the American neoconservatives, who were the major cheerleaders for the invasion, led coalition forces into a morass from which it has been difficult to find any way out.

The Australian Army arrived at 2001 undermanned, underequipped and unprepared for what unfolded in the first decade of the 21st century. It was not ready for what became and remains a series of concurrent, competing and at times intense global missions.

On 10 September 2001, who would have imagined that Australian troops might soon deploy to Afghanistan? In October 2001, as Australian special forces deployed to Afghanistan, who would again have imagined that inside 18 months Australian special forces would launch into the western desert of Iraq? For both countries, there were many unanswered questions: who had the maps; how would the force get there; what language did the locals speak; was the right clothing and equipment available?

This quote from Palazzo states the situation very clearly:

From the perspective of the stocks available the reality was that in mid-2002 little of the Australian Army's order of battle was readily deployable for a war with Iraq, even against an opponent that would prove as strategically, operationally and tactically inept as the regime of Saddam Hussein. ${ }^{15}$

14 D. Wroe, 'The secret Iraq dossier', Sydney Morning Herald, 25 February 2017.

15 Palazzo, The Australian Army and the War in Iraq: 2002-2010, p. 172, www.smh.com.au/ interactive/2017/pdfview/ViewerJS/\#../The_Australian_Army_in_Iraq.pdf (retrieved 3 April 2020). 
Haunted by the memory of what happened to the unprepared Australian infantry units rushed into battle on the Kokoda Track in the Second World War, the ADF should know well the dangers of deploying inadequately equipped and prepared troops into combat. Troops should not be asked to accept this level of risk. The risk should be mitigated before conflict. The responsibility to address this risk lies with government and its fundamentally important dual functions of determining strategy and allocating appropriate budgets. Government is not entirely to blame as the military have not been particularly competent at articulating this risk to government. In part this is because the Australian Army has tended to focus on developing skills at the tactical level and up to the operational level of war. We have tended to leave the strategic level to others to manage.

The operational level of war is generally taken to be how a strategy is achieved by assigning missions, tasks, timings, geographic boundaries and resources. It is the ways and means portion of Liddell Hart's strategic equation. Important operational lessons for Australia from Afghanistan and Iraq are: demand, designing the force, equipping the force, doctrine and whole-of-government intent.

The hallmark for the period from 1999 to 2017 was the duration and consistency of the demand for combat forces. This showed that the force, as at 2001, was not large enough to sustain multiple operational deployments. Subsequent decisions taken, during the decade, to expand the force through such programs as the Hardened and Networked Army and the Enhanced Land Force have somewhat eased the pressure. However, there remain limits to what the ADF can do. Further expansions and force structure adjustments to all three services might still be necessary to cope with ongoing demands and future contingencies. One way of dealing with high demand is to adjust the duration of deployments. Longer deployments of individuals and formed bodies mean fewer troops are required. Of course, the situation has not been as bad as during the Second World War when troops went to war unsure of how long they would be away and when the Australian auxiliary forces included the equivalent of 14 divisions - a stark contrast to the far smaller Army of the early 21 st century.

The initial deployments to the Middle East, in 2001 and 2003, were set at six months. This was on the basis that a prolonged campaign was not anticipated, the intensity of operations was not expected to be high, and six months was considered a reasonable time for individual and unit 
deployments. As pressure came on from other deployments in Bougainville, Iraq, Solomon Islands and East Timor, the immediate solution to concurrency pressures was to extend the duration of deployments and to limit the nature and type of tasks accepted from the coalition. This took careful management and explanation.

Multiple deployments to multiple theatres take a toll on individuals and their families. One significant aspect of managing demand for combat readiness since the start of the century is that there has been little respite for many elements of the ADF. Much has been asked of our soldiers, sailors and airmen and their families, and they have delivered magnificently.

Decisions to commit forces to an operation are taken at a political level. These decisions, while conscious of the need to deploy force, are not always conscious of the appropriateness and availability of the force. This was particularly so in the context of deployments to Afghanistan and Iraq. Designing suitable forces took a lot of negotiation, manoeuvring and management with government and with coalition partners. In the case of Afghanistan, in 2001, there was no realistic choice other than to send the SAS Regiment. This was also the case in the March 2003 deployment to Iraq. They were the most ready and appropriate forces for the assigned tasks. Beyond these initial deployments, an enormous amount of work was required to determine the task to be undertaken in follow-on phases and then prepare the appropriate forces.

It is no secret that the United States would have preferred that Australia offered more powerful, versatile, combat-oriented forces. The forces that deployed were a product of the available forces, their capability and the assessment of the risk. The Army was particularly concerned about the lack of armoured protected mobility and firepower available for deployment to Iraq in 2005. Once the task and appropriate force were determined, the force then had to be regrouped and prepared. The fact that the force eventually deployed to Al Muthanna as a combined arms group (made up of 52 different units), rather than an established unit, is a telling comment on the inappropriateness of the unit, regimental and corps structures of the day. 
In the early days, the Army was not good at designing deployable forces. Things were often rushed and haphazard. Forces were 'going, ready or not'. It was only in later deployments that a system was developed that appropriately trained, prepared and assessed the force and formally handed it over for deployment to Joint Operations Command.

Any deployed military force should have the best equipment. In the early part of the deployments to Afghanistan and Iraq, the extant defence procurement system was unable to cope with the demands of the deploying forces. It was not responsive enough to match the rapidly changing requirements and too slow to deliver the necessary equipment. Peacetime procurement processes proved to be totally inappropriate. It was only with the introduction of a hastily developed rapid acquisition system that deployed forces began to be supplied with the right equipment in a timely manner.

In the early days of both deployments, there were many pronouncements about how these would be whole-of-government deployments whereby a range of government agencies beyond the Defence portfolio would engage and assist in accomplishing the assigned missions. But there was more talk than action. In the deployments to both Afghanistan and Iraq, AusAID was seldom seen in the field, and in Afghanistan AFP elements were largely confined to the base at Tarin Kowt. Things improved somewhat over the years, but issues of security, protection and capacity will always be a constraint on what civilian agencies can do. An exception was Australia's external intelligence agency, the Australian Secret Intelligence Service, which gave sterling support providing an intelligence edge to Australian soldiers in the field. ${ }^{16}$

Achieving the appropriate balance between security, stability and development will always be a difficult task. The military are clearly not the best force to be involved in the detailed work of development and delivering aid, but sometimes they are the only force available and able to do the task safely. One of the few official 'lessons learned' documents authored principally by Ric Smith and published by the Australian Civil-Military Centre was Afghanistan: Lessons from Australia's Whole-of-Government Mission. It is a rather narrow report, which by its own admission does not evaluate the effectiveness of the effort in Afghanistan but merely identifies

16 N. Warner, 'ASIS at 60', 19 July 2012, www.asis.gov.au/about-us/speech.html (retrieved 30 April 2020). 
a number of areas worthy of consideration when planning and responding to future contingencies. It provides little tangible discussion to enhance the whole-of-government discussion. It acknowledges that it was not until April 2009 that the whole-of-government approach saw significant deployments of civil elements into the field-more than seven years after troops first deployed to Afghanistan following the 9/11 attacks. It also acknowledges that at the policy level, interdepartmental involvement was relatively light in the early period but intensified from 2006 until it acquired a more genuinely whole-of-government character by $2009 .{ }^{17}$

The report recorded 17 key lessons. ${ }^{18}$ Included among them were the need to:

- involve all relevant departments and agencies in whole-of-government policy development and planning from the outset

- establish a senior-level, inter-agency group to oversee policy development and provide a high-level nexus with the National Security Committee of Cabinet and the Secretaries' Committee on National Security

- agree principles and protocols to be developed at the outset of the mission to define working relationships and responsibilities between different services and agencies

- establish a cross-agency public affairs capability to highlight the whole-of-government nature of the mission.

An area where commanders, in the field, were left with little support was in the development of doctrine. In both Afghanistan and Iraq, the campaigns rapidly morphed into a counter-insurgency effort with a constantly changing balance of tasks around the four-phased concepts shape, clear, hold and build. Commanders on the ground saw the need to support the local population and set about doing so on their own, but without adequate doctrine. Doctrine was eventually developed and was influenced by the experiences of those on the ground. Supporting this effort was an increased focus on immediate lessons learned, which were fed directly back into the force preparation cycle and mission rehearsal exercises.

17 Australian Civil-Military Centre, Afghanistan: Lessons from Australia's Whole of Government Mission, ACMC, Queanbeyan, p. 7.

18 Ibid., pp. $8 \mathrm{ff}$. 
In many ways, the deployments were set-and-forget missions. By deploying, Australia had achieved the coalition aim: there were flags on the table. Commanders were certainly left to cope with changes to the operational environment without adequate strategic guidance. Commanders in the field stated that they received little strategic guidance on what their objectives were. ${ }^{19}$ They were right to complain.

Moving beyond the issue of operational lessons lies the issues of legacies. A legacy is a gift or bequest handed down from those who have gone before. They are significant issues that shape the nature of the force and how it fights and how it is perceived by the public and the international community. The Anzac legacy of service and sacrifice is an example, and Australian forces deployed to the Middle East have proudly sustained and added lustre to the legacy of those who went before them.

It is too soon to identify clear legacies from the current experience of Australia's niche wars in Afghanistan and Iraq. However, there are three likely candidates: the decision-making process to go to war in the first place, the influence of the US alliance on Australian calculations, and the limitations in the treatment of wounded veterans.

Observations from the United Kingdom and the United States question the wisdom of the decision to go to war in Iraq. In Australia, where the prime minister reserves to him- or herself 'crown prerogative' on the decision to go to war, it is unacceptable, except in the case of a defence emergency, that the nation can be taken to war without parliament and the public being fully engaged.

Today, after nearly 20 years, Australia remains at war in Afghanistan and Iraq. For both locations, there has been very little public discussion or debate on the decisions to go to war and the daily repeated decisions to stay at war. Apart from relatively minor changes, Australia's strategywhat there is of it -in both places has remained the same. This is no way to make national security decisions. Such an approach is a disservice to the public and to those in the ADF required to deploy on multiple occasions to combat operations over such a long period.

19 Various conversations with the author. 
As some express concern over the decisions President Trump might make, the historic and almost automatic response of Australia to become involved in the United States' wars is of concern. The United States, let alone the rest of the world, has yet to be convinced of the wisdom and maturity of Trump's foreign policy choices and actions. Where might a new US president take Australia, and is there any assurance that an Australian prime minister, in exercising crown prerogative, might not exercise similarly poor judgement?

There is cause to review crown prerogative. George Williams, Dean of Law at the University of New South Wales, in an opinion piece wrote:

Parliament should pass a law requiring that it debate any proposal to commit Australian troops. A decision by the Prime Minister to go to war should also be subject to a veto by a majority vote of both houses of the federal Parliament. This would provide a much-needed circuit breaker, thereby reducing the possibility of Australia taking part in another inadvisable foreign conflict. ${ }^{20}$

Under a convention introduced in 2011, Britain is required to take deployment decisions to parliament for debate. ${ }^{21}$ The United States has the War Powers Act, and in Russia, President Putin in 2015 asked the Russian parliament for authority to bomb in Syria. Australia is alone, among its major allies and world powers, regarding the decision to go to war. An initiative to engage parliament in decisions to go to war such as those proposed in the Defence Amendment (Parliamentary Approval of Overseas Service) Bill 2010 [No. 2] would be a fitting legacy of the Australian experience in Afghanistan and Iraq. ${ }^{22}$

The ANZUS Treaty is a key element behind the choices that Australia makes about going to and staying at war. Some argue that to guarantee continued benefit from the alliance, Australia needs to be involved in all US military activities. Their fear is that if requests from the United States for support are declined, then the United States might not respond to Australian requests for support in the event of a future defence or security emergency.

20 G. Williams, 'Why Australia must learn from our mistakes in the Iraq War', Sydney Morning Herald, 27 March 2017, newsroom.unsw.edu.au/news/business-law/why-australia-must-learn-ourmistakes-iraq-war (retrieved 24 April 2020).

21 C. Mills, 'Parliamentary approval for military action', House of Commons Library, 13 May 2015.

22 S. Ludlam, 'Debate on the War Powers Bill', 7 July 2011, scott-ludlam.greensmps.org.au/articles/ debate-war-powers-bill (retrieved 3 April 2020). 
There can be no disputing that the alliance with the United States is important to Australia. The ADF gains privileged access to intelligence, technology, armaments, logistics and strategic lift. The result is that Australia is more powerful and influential than it could ever expect to be without the alliance. However, a balance must be achieved between sustaining the alliance for capability and security reasons, and meeting Australia's sovereign national interests. This leads to the question: does Australia's level of dependency on the US alliance hinder its ability to make independent decisions based on its own national security interests?

Given the emerging judgements on the intervention in Iraq, and the apparent intractable nature of the conflict, questions must be asked about whether going to Iraq was the right thing to do. As with Afghanistan, the fundamental question is whether the Australian commitment was about supporting the alliance or acting to support its own national interests, be they security, moral or humanitarian.

It is a good thing that Saddam Hussein is gone, but while democracy and secularism have been introduced in Iraq, they have not taken a firm hold. The situation in Afghanistan is similar and becoming worse. Despite 16 years of a coalition presence in the Middle East, the terrorist base has expanded, democracy has not taken hold, there is unprecedented turmoil and Western influence has been diminished in part to be replaced by Russia, Turkey and Iran.

It is difficult to imagine the future circumstances in which US and Australian interests might not coincide, but Australia must be alert to the potential for our interests to diverge and be prepared to say no to any request from the United States to deploy forces to a conflict that is not clearly in our national interests.

During the 'Long Peace', the ADF, with tight personnel ceilings, had little room for those who were not able to meet fitness and readiness standards. Those with injuries were generally discharged quickly. As combat operations began and casualties occurred in both Afghanistan and Iraq, many quite rightly started to question these quick discharges. Surely those who were wounded in battle were owed time to recover from their wounds and, if possible, the option to continue their careers, to the best of their ability, in the ADF. Why would soldiers go forward into battle if they were not going to be looked after if they were wounded? The ADF 
was not adequately prepared to meet this obligation to its soldiers, sailors and airmen. The turnaround occurred but only after some solid prodding of the Defence bureaucracy.

There are three primary areas requiring improvement: the medical treatment and retention of the physically and psychologically wounded while in-service, the official government support provided to veterans after discharge, and the community support that can also be provided after discharge. Once the obligation to the wounded was recognised, the care and attention provided inside the ADF has been world class. One lingering area of concern is that those with psychological injuries tend to be discharged rather quickly, which means that injuries of this type are sometimes not declared and are therefore untreated or at least independently managed.

The Department of Veterans' Affairs does a commendable job of caring for the wounded once they are discharged. Regrettably, the department suffers from a less than desirable public image, but is aware of this and is pursuing internal reforms. These reforms need to be expedited. Everyone eventually leaves the military with most fitting back into the civilian community with little trouble. Some among the approximately 72,000 who have served in the ADF since 1990 with physical and psychological wounds find it more difficult to reintegrate into civilian life. For many, their recovery will be a lifelong journey during which they will need the support of their family, friends and the broader Australian community. In the last five to 10 years, a number of newly formed community-based organisations have been making a significant additional contribution to support veterans and assist in their successful reintegration to the country. These organisations should be encouraged as they develop a new community-based approach to caring for our wounded.

\section{Conclusion}

The Australian Army has been through a period of intense operational tempo over nearly two decades. Deployments have been global and continuous. They have varied greatly in nature and intensity. A great number of lessons have been learned, and their realisation has made the force more robust and combat ready and better able to cope with future demands. 
Overall, the deployments have been handled adequately, and the Australian Army, although at times hard pressed, has provided government with manageable options and combat-ready forces. However, these forces were heavily restrained by the capabilities of the force in being in the early stages of both deployments. They remain so today. This means that the focus has been on protection, training, mentoring and support tasks rather than offensive missions.

Risk has been managed but, in the early stages of both deployments, was weighted towards the individual soldier rather than residing where it should be at government level. To mitigate this risk, government must provide realistic strategic guidance and adequate budgets. Neither were in place in 2001 and 2003 and, in many respects, are still not in place now.

The major lessons from the conflicts have been around honouring Basil Liddell Hart's strategic equation of the necessary ways and means to achieve the desired ends. This has not been done well, and there have therefore been considerable difficulties around articulating a strategy and assigning missions. So too were there problems in meeting the demands for combat forces, designing the force, equipping the force, developing relevant doctrine and providing a functional whole-of-government effort.

There are no clear legacies from these conflicts, but there are three candidates: first, the development of a parliamentary convention to debate and approve the commitment of ADF elements to conflict; second, the realisation that committing forces should not be based solely or even primarily on protecting the alliance but on clearly articulated Australian national interests; and third, an obligation to look after the wounded and a dedication to making them the best reintegrated generation of soldiers in our nation's history.

Although some lessons have been learned during the period 2001-14, there are more to be learned from current operations. As of mid-2020, the ADF remains in Afghanistan and Iraq, and the world order is under unprecedented strain. There is more work to be done, and Australia will be involved. The obligation to learn from the effort and sacrifice of our soldiers in Afghanistan and Iraq is a sacred one that must be honoured. 
This text is taken from Niche Wars: Australia in Afghanistan and Iraq, 2001-2014, edited by John Blaxland, Marcus Fielding and Thea Gellerfy, published 2020 by ANU Press, The Australian National University,

Canberra, Australia.

doi.org/10.22459/NW.2020.18 